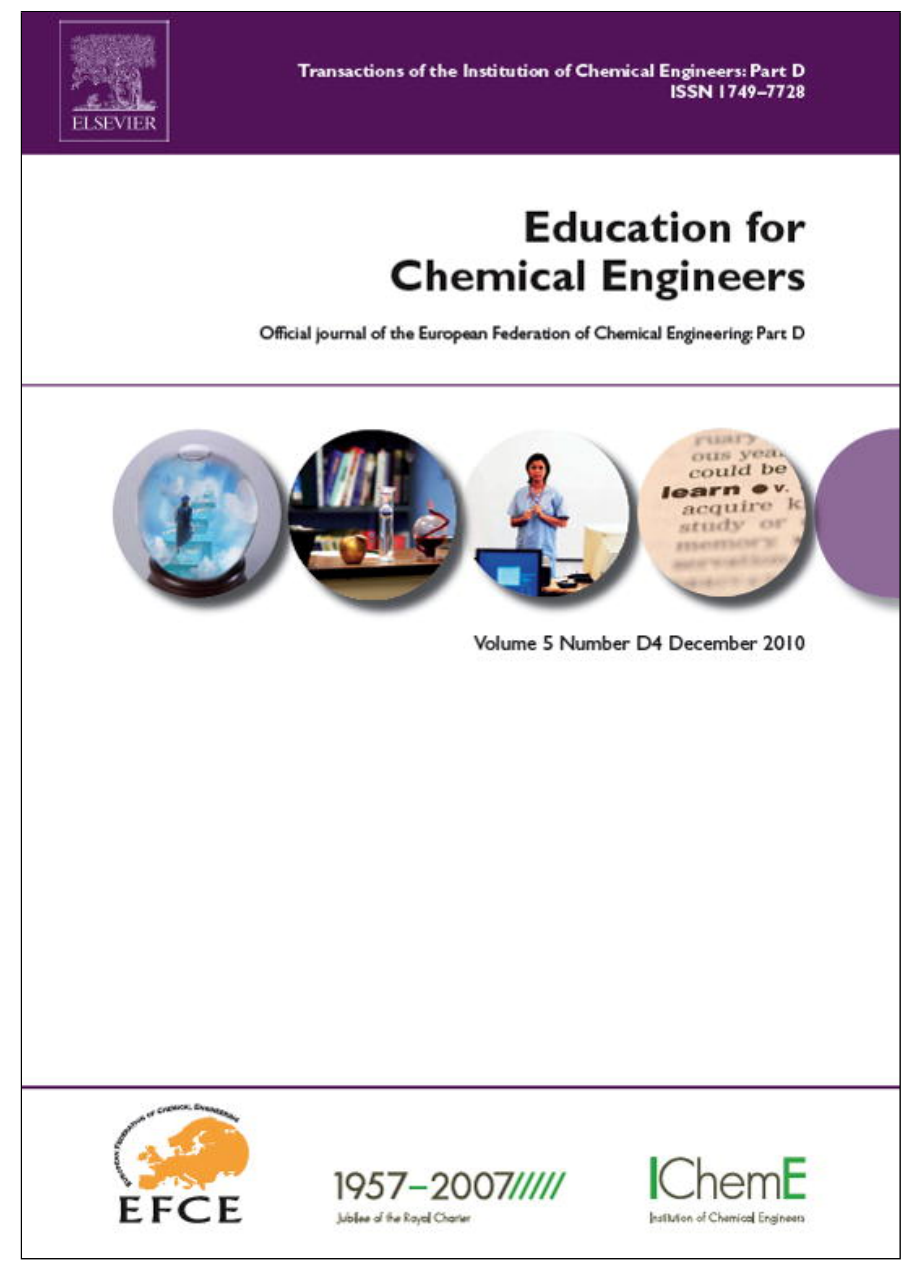

This article appeared in a journal published by Elsevier. The attached copy is furnished to the author for internal non-commercial research and education use, including for instruction at the authors institution and sharing with colleagues.

Other uses, including reproduction and distribution, or selling or licensing copies, or posting to personal, institutional or third party websites are prohibited.

In most cases authors are permitted to post their version of the article (e.g. in Word or Tex form) to their personal website or institutional repository. Authors requiring further information regarding Elsevier's archiving and manuscript policies are encouraged to visit:

http://www.elsevier.com/copyright 


\title{
Encouraging engineers to read: A book-based final year assessment
}

\author{
Grant M. Campbell ${ }^{a, *}$, John Blunden-Ellis ${ }^{b}$, Frank Manista ${ }^{c}$ \\ a School of Chemical Engineering and Analytical Science, University of Manchester, United Kingdom \\ $\mathrm{b}$ John Rylands University Library, University of Manchester, United Kingdom \\ c Centre of Excellence for Enquiry-Based Learning, University of Manchester, United Kingdom
}

\begin{abstract}
A B S T R A C T
This paper describes an initiative within the final year of the MEng Chemical Engineering programmes at the University of Manchester, in which students were required to identify a suitable book, broadly related to chemical engineering, and read it and be assessed on it. Meanwhile a similar number of academic staff also read the books in order to prepare the assessments. The reading was supported by a programme of lectures and discussion groups to engage students with the book as a concept and with the nature of reading more generally, in order to enhance and empower their own reading. The examination included assessment of these generic aspects as well as the students' technical mastery of their specific books. Feedback on this initiative was extremely positive as a refreshing alternative to traditional forms of teaching and learning employed in chemical engineering, and as encouraging enhanced skills in communication and greater empowerment to read as the basis for lifelong learning.
\end{abstract}

(C) 2010 The Institution of Chemical Engineers. Published by Elsevier B.V. All rights reserved.

Keywords: Books; Reading; Education; Communication; Lifelong learning

\section{Introduction}

Engineers as a group are traditionally not great readers. Even those who enter academia can soon lose the habit of reading entire books, or struggle to justify the necessary time commitment. Books tend to be consulted rather than read, dipped into for data rather than being immersed in for knowledge and understanding. However, books read in their entirety convey ideas and give a coherence of thought and rationality that cannot be gained from selective consultation without context. Meanwhile, problem-solving engineers operate in a world in which the questions asked are increasingly complex, requiring ever enhanced quality and coherence of understanding in order to conceive and implement solutions. It is important that engineering graduates (and the academics who teach them) should be encouraged and enabled to read books, as the basis for enhanced and ongoing effectiveness.

To this end, a book-related teaching activity was conceived and implemented within the final year of the 4-year integrated masters programmes in chemical engineering at the University of Manchester. This was envisaged as "a student- driven learning activity based around the directed reading of a book relevant to the broader context of chemical engineering." Three broad benefits from this "Book Module" were expected:

(i) first and foremost, a systematic and formalised approach to encouraging engineering graduates to view books as accessible and to have the inclination and interpretive tools to engage with them as a basis for lifelong learning;

(ii) the opportunity for individual students to direct their learning towards areas of specific personal interest, through selection from a diverse pool of relevant books; and

(iii) a redirection of the teaching 'burden' such that staff too are encouraged and enabled to make time for reading, with this otherwise luxury having the legitimate and tangible outcome of being directly connected to teaching.

Funding for this initiative was kindly provided by the Centre of Excellence for Enquiry-Based Learning (CEEBL) at the University of Manchester, in order to allow the purchase of the books. This paper briefly overviews the literature on the rela-

\footnotetext{
* Corresponding author. Tel.: +44 161306 4472; fax: +44 1613064399.

E-mail address: grant.campbell@manchester.ac.uk (G.M. Campbell).

Received 19 April 2010; Received in revised form 19 July 2010; Accepted 16 August 2010 1749-7728/\$ - see front matter @ 2010 The Institution of Chemical Engineers. Published by Elsevier B.V. All rights reserved. doi:10.1016/j.ece.2010.08.002
} 
tionship of reading to education, the extent to which reading features within the sources by which engineers obtain information, and the benefits to scientists and engineers of reading. It then describes the implementation of the Book Module within the School of Chemical Engineering and Analytical Science's undergraduate masters programmes, and evaluates its success.

\section{Reading, education and engineers}

"Until lately the West has regarded it as self-evident that the road to education lay through great books." So opens Robert Hutchins' The Great Conversation: The Substance of a Liberal Education (1952, xi), which serves to introduce the Great Books of the Western World series. (The substance of this series is on great works of philosophical, religious, historical, dramatic, scientific, medical, economic and political literature produced within Western civilisation; the series includes Homer, Plato, Aristotle, Augustine, Chaucer, Shakespeare, Descartes, Newton, Gibbon, Kant, Fourier, Darwin, Marx and Freud, to name but a few.) Hutchins goes on to observe (page xiv) "the disappearance of great books from education and from the reading of adults constitutes a calamity... the idea that a liberal education is the education everybody ought to have, and that the best way to a liberal education in the West is through the greatest works the West has produced, is still, in our view, the best educational idea there is." (italics added.)

As educators in universities, it seems appropriate to pay attention to "the best educational idea there is." To be fair, Hutchins' argument is specifically in relation to these literary classics, but it is more generally true, albeit at a more prosaic level, that education and reading are considered to go hand in hand. Covey (1989) in his Seven Habits of Highly Effective People notes (pp. 295-296) "It is extremely valuable to train the mind to stand apart and examine its own program. That, to me, is the definition of a liberal education - the ability to examine the programs of life against larger questions and purposes and other paradigms. Training, without such education, narrows and closes the mind so that the assumptions underlying the training are never examined. That's why it's so valuable to read broadly and to expose yourself to great minds. There's no better way to inform and expand your mind on a regular basis than to get into the habit of reading good literature... 'The person who doesn't read is no better off than the person who can't read.' "With similar force, Pandian (2000) (quoted in Abdul Karim and Hasan, 2007) describes 'reluctant readers' as "people who are 'retarded' in terms of knowledge, intelligence and maturity.", while Salwak (2008, pp. 70-71) comments "I can't even begin to imagine how a nation of nonreaders will effectively communicate, solve problems, and engage with citizens within and beyond its borders without the reservoir of understanding and knowledge stored within books."

These arguments for the foundation of education being in reading seem to be relevant for the education of engineers. The stereotypical picture of an engineer does not include a book in the engineer's hand; engineers are not generally regarded as great readers. Taraban (2006) goes further to note that "A bit of scepticism may surround the idea that effective reading has much to do with engineering." Engineers also tend to be resistant to change (Tenopir and King, 2004, p. 44), suggesting also a reluctance to "examine... against other paradigms" which reading encourages. However, Tenopir and King (2004) examined exhaustively the communication patterns of engineers. They noted that engineers, particularly design, R\&D and consulting engineers, are prolific seekers and users of information (pp. 31, 48). In contrast with scientists, however, engineers favour information retrieval via personal, oral communication rather than from the literature (pp. 61, 75). Although engineers do in fact read quite a lot, the source material for their reading is biased heavily in favour of internal reports and trade magazines rather than scholarly journal publications or books. Nevertheless, a persistent finding is that those engineers who do read a lot are more successful than those who do not. Lufkin and Miller (1966) surveyed the reading habits of engineers and concluded "The people who have been singled out for excellence, whether by promotion, or by publication, or by special recognition for creativity, all read a great deal more than the average", a relation that has been confirmed in subsequent studies (Tenopir and King, 2004, pp. 43-44). A pragmatic and utilitarian consideration for engineers then, rather than the noble aspirations of a liberal education, is that a habit of reading tends to be associated with professional success.

Engineers do read, but tend not to read books in their entirety, reading instead primarily to obtain information from whatever sources are most readily accessible and trusted. But T.S. Eliot lamented "Where is the wisdom we have lost in knowledge? Where is the knowledge we have lost in information?" (thus inspiring the Information Science framework of Data-Information-Knowledge-Wisdom (Anon, 2009)). With their focus on information, engineers are in danger of failing to develop the wisdom required to address the problems and challenges of the modern world - of being "retarded in terms of knowledge, intelligence and maturity" - of being trained but not educated. This is where books have a unique power, relative to the other forms of written communication with which engineers and other professionals engage. As Hutchins (1952, p. 47) observes "Great books are great teachers... they demand the attention of the reader and keep his intelligence on the stretch." Books have a depth, complexity and coherence that give them an educational value beyond other forms of written communication.

The United States' Accreditation Board for Engineering and Technology (ABET) has as one of its criteria for the accreditation of university engineering programmes "a recognition of the need for, and an ability to engage in, life-long learning" (Spurlin et al., 2008, p. xxi); the UK Standard for Professional Engineering Competence (UK-SPEC) similarly recognises the need for lifelong learning (Anon., 2004). Once graduates leave university, teaching and learning will no longer be served on a plate. Who, then, will be the lifelong teachers of engineering graduates? And on what basis might an engineering programme demonstrate that it is giving its graduates the ability to engage in lifelong learning? If great books are part of the answer to the first question, then inclining students towards books might well be considered an appropriate answer to the second.

Reading of books is widely recognised as foundational for education. The anecdotal and formal evidence that engineers are not great readers implies a worrying conclusion regarding their status as "educated". Therefore the motivation for the current work was to enhance the educational status of our engineering graduates by exposing them to the reading of books both as a concept and as a reality. 


\section{Approach}

This section describes the practicalities of how the Book Module was incorporated within the degree programmes of the School, how it was 'sold' to students and to staff, how it was operated, how the students were assessed, and how the project was evaluated. The Book Module has now operated for two academic sessions. Its introduction in the 2008-2009 academic session has been documented by Campbell et al. (2010) in the collection of case studies published by CEEBL. The current paper updates the case study by drawing on an additional year's data from the 2009 to 2010 academic session.

\subsection{Incorporating the Book Module within the undergraduate MEng programmes - and getting staff and students on board!}

The School of Chemical Engineering and Analytical Science at Manchester (CEAS) runs several undergraduate integrated Masters programmes: the straight MEng in Chemical Engineering, MEng with Biotechnology, MEng with Environmental Technology, MEng with Chemistry and MEng Chemical Engineering (Business Management). (The use or otherwise of brackets reflects the university's regulations on the naming of joint degrees.) The first three of these MEng programmes are taught entirely with CEAS, drawing on research expertise within the School to provide the distinctive content, while the latter two involve modules delivered by the School of Chemistry and the Manchester Business School, respectively. The final year of these programmes is dominated by a Research Project and Dissertation, which comprises 50 credits out of the total of 120 for the year. (CEAS also runs the MEng with Industrial Experience and the MEng with Study in Europe, in which students spend their third year in industry or at a European university. These students return for a final year that does not involve a research dissertation, but instead features the 30 credit Design Project that is a requirement of an accredited engineering degree programme. The BEng with Industrial Experience, the BEng (Hons) and the BEng (Ord) make up the total of ten undergraduate chemical engineering programmes offered at Manchester.)

The Book Module was implemented as a 10-credit unit within the final year of the straight MEng programme, the MEng with Biotechnology and the MEng with Environmental Technology. It was not included within the Chemistry and Business Management programmes, because their timetables require a certain number of credits from the external Schools, such that there was no room for the Book Module. It was not included within the programmes for which the students are away from the university for their third year of study, because of the obligation to fit sufficient specified engineering content into their final year of study.

The Aims of the Book Module were described in the Undergraduate Student Handbook as:

To allow students the opportunity to develop in-depth knowledge in a subject area of their choice, closely or loosely related to their research project or more broadly to chemical engineering, through reading and mastering a book on the subject.

To develop an appreciation of the unique features of books as communication media, and to give students the skills and inclination to engage with books as the basis of lifelong learning and ongoing education. while the Intended Learning Outcomes were that the student should be able to:

Describe, insightfully and engagingly, the content, merits and significance of a selected book.

Demonstrate mastery of the subject matter of a selected book and understanding of its context within the discipline and practice of chemical engineering.

Communicate an appreciation of the advantageous and disadvantageous features of books, compared with other communication media.

The Book Module was introduced for the academic session 2008-2009, for which there were a total of 35 students on the five 'standard' MEng programmes, of which 23 were on the three programmes that included the Book Module. Originally it was intended that a limited selection of around four or five books would be offered, from which students would select one, such that a group of students would be reading a given book and could discuss it and learn together. However, it was decided to try to align the student's choice of book with their Research Project, and to have the Research Project supervisor read the book in order to provide the assessment. This was clearly a more ambitious endeavour, requiring the involvement of a larger number of academics, with greater issues over comparability of books and of assessments, as well as logistical issues over identifying and obtaining the books within a reasonable timescale. It also meant that most books were read by a single student, precluding opportunity for detailed technical discussion and cooperative learning. In the end, a pragmatic, hybrid system was implemented, on the basis that a very small number of academic staff simply refused to participate, while others, while being willing, were not actually competent to read and prepare an assessment for the book their student was wanting to read. (For example, one student chose a straightforward chemical engineering textbook, "Dispelling chemical engineering myths", but his research project supervisor was a chemist with limited chemical engineering understanding; the supervisor was willing, but it was decided to have a chemical engineer read the book instead.) The Book Module was run similarly in the 2009-2010 academic session, with a cohort of 33 students out of a total of 49 students on the five 'standard' MEng programmes.

The module had been 'sold' to staff on the basis that: (i) that they could keep the book, so this was an opportunity to obtain a book they had had their eye on; (ii) that this gave them the encouragement and opportunity to read a book that they might otherwise struggle to find time to do; (iii) that this was educationally 'a good thing' to be doing with our students, this in itself being sufficient motivation to do it. Most staff were willing in principle, one commenting "I think the Book Module is a great idea!", but also confessing "I can't remember the last time I read a book!"

To introduce and sell the idea to the students, they were gathered for an introductory session at the beginning of the year, having spotted this strange new "Book Module" in their timetables. They were told "This year, instead of us academics reading, predigesting and serving up knowledge to you, you will have to read a book yourselves, master its content, and be ready to sit an exam on it". While several of the students were delighted with this opportunity, many looked aghast, some commenting "B-but. . I don't read books!" The Business Management and Chemistry students were then highly relieved to discover that they did not have to do this module. It is thus 
fair to conclude that the initial response by the students was predominantly of apprehension, with a few highly supportive, and the rest simply resigned. The introductory session then continued by presenting the motivations for the module in terms of the accepted educational benefits of reading and the limitations of engineers who fail to read. Not necessarily convinced, the students were thus informed that they were obliged, in discussion with their Research Project supervisor, to identify a book and get it approved by the Book Module coordinator, who then, via the university Library and with the CEEBL funding, arranged to purchase the books.

\subsection{Operating the Book Module}

As noted above, a few supervisors refused to read a book alongside their student, or preferred not to if possible, while others were very willing to engage. Thus, a pragmatic approach was taken to ensure that a book was identified for each student and read by a suitable academic. Iteratively over several weeks, as books became agreed by a particular student and supervisor, those books were also offered to other students via a regularly updated list. Meanwhile, as other students identified books that their supervisor was unwilling to read, an alternative academic was identified to read the book (usually the module leader, who ended up reading several books). Thus, ultimately, in 2008-2009 a total of 19 books were read by 23 students and 16 academics; in 2009-2010, a total of 24 books were read by 33 students and 22 academics. Issues included, of course, ensuring students chose books that were roughly equivalent in terms of size and difficulty. The module leader provided guidance regarding length (200-300 pages, as a rough guide) and took an overview regarding the suitability of each book. The books were required to be broadly relevant to chemical engineering, but chemical engineering is the broadest of the engineering disciplines (Perkins, 2003) and a very broad view was taken regarding relevance. (Thus, for example, one book was on the history leading up to the Industrial Revolution, as the student was interested in history, and the Industrial Revolution is intimately linked with the rise of the chemical industries and the development of chemical engineering as a discipline.) In some cases, equity in terms of the size of book was approached either by requiring a student to read only selected chapters of a longer book, or by supplementing a shorter book with another book chapter or related review article. (Thus, for example, the history book mentioned above was only 192 pages, with many illustrations, so was supplemented in 2008-2009 with a 30-page book chapter on "Chemical Engineering - the First 100 Years", and in 2009-2010 (having been chosen again by one student) with a chapter from "The Ascent of Man" by Jacob Bronowski.) The size and difficulty of the chosen book was also taken into consideration later when assessing the student's examination script.

Having chosen the books, and having understood they were obliged to read and master these themselves as independent learners, the students' engagement with their books was nevertheless facilitated through a structured programme of lectures and discussion groups. As well as the introductory lecture, a lecture was scheduled entitled "The Concept of the Book". This lecture was delivered by Mr. John Blunden-Ellis of the John Rylands University Library, whose remit includes library provision for chemical engineering, and who regularly contributes seminars on library and information provision for undergraduate and postgraduate programmes and activities in CEAS. It was intended that the Book Module should not only develop technical mastery of the particular book chosen by the student, but would also serve to cultivate an appreciation of books and the nature of reading in general, in order to encourage and facilitate ongoing reading as the basis for lifelong learning. Thus the lecture covered four main topics: the evolution of the book; the present status and likely future of the book; the nature of reading and how we deal with information (in particular, contrasting reading books with reading from the internet); and the way in which engineers obtain information, in particular highlighting the documented benefits to professional scientists and engineers of reading.

As well as the lecture, two discussion groups were held, in order to give students a forum for discussing their book in terms of its nature and content and their reaction to it (and to ensure that students were reading their books in a timely fashion). In 2008-2009, it so happened that many of the books were related to energy, so one of the discussion groups was devoted to these books, while the second featured a more eclectic range. In 2009-2010, with the larger numbers of books and students, both discussion group sessions were eclectic. As well as giving the students opportunity to verbalise the subject of their books, these discussion groups emphasised a critical consideration of the nature of each book, in terms of, for example, literary devices it employed or failed to employ, and how it sought to structure its material and to engage with the reader. This activity, in relation to each student's own book and in comparison with the other books, served to help students see and appreciate the nature of books and the structures and devices employed in written material to inform and engage. Having this appreciation, it was hoped, would encourage and empower students' future reading of books.

\subsection{Assessing the students' achievement on the Book Module}

The Book Module contributed 10 credits to the final year of the MEng programme, which is made up of 480 credits in total. These are split equally over the four years, but the final years are weighted more heavily in relation to deciding a student's degree classification, the weighting being 1:3:6:6 for the four years. It was important, therefore, to design adequately robust and accurate assessments for this module, within the context of its contribution to the students' degree classifications.

The module was assessed via a book review and a written exam. The book review was undertaken to help the students engage with their books, and contributed $10 \%$ to the overall assessment for the module. The written exam contributed the other $90 \%$, and comprised three sections covering:

A) Generic questions on the book as a concept and the nature of reading, drawing largely on the "Concept of the Book" lecture and associated material, and contributing $20 \%$ (increased to 25\% in 2009-2010): e.g. "Contrast the nature of reading when applied to the Internet with that applied when reading a book. What are the relative merits and disadvantages of these two broad extremes of reading style? Given that engineers tend to do less of the latter, what are arguably the benefits to engineers and scientists of more reading of books? Support your answers with reference to relevant research in these areas.";

B) Generic questions about books and reading, answered in relation to each student's particular book, contributing 30\% (reduced to 25\% in 2009-2010): e.g. "Discuss how the author(s) of your book sought to engage the reader, i.e. devices or approaches they employed that sought to go beyond merely 
providing information, but sought more ambitiously to involve the reader and to draw them into 'The Great Conversation'.";

C) Specific questions related to the technical content of each book, contributing $40 \%$.

The questions for parts A and B were devised by the module leader in consultation with John Blunden-Ellis of the library and Frank Manista of CEEBL, while the specific questions for each book were provided by the academic staff members who had read the books, with the module leader advising and taking an overview with respect to the length and difficulty of the questions for each book. The 19 books in 2008-2009 resulted in an exam paper of 23 pages in length, while in 2009-2010 the 24 books gave an exam paper of 31 pages, on each occasion the largest exam paper offered across the Faculty of Engineering and Physical Sciences! The examination papers were sent to the External Examiner, who was kept informed of the nature of this initiative and was approving of it. The examination was $2 \mathrm{~h}$ long, unseen and held under examination conditions, but 'open book' in relation to the particular book the students were studying, i.e. they were allowed to bring that book, but no other material, into the exam.

The book reviews and sections A and B of the exam were assessed by the module leader, while section $C$ was assessed by the academic staff member who had read the particular book. Thus, the majority of the marking was performed by the same academic, thus ensuring equity of marking for the majority of the assessment. Equity on part $C$ was sought by providing instructions in the form of descriptors of the type of answer that would attract a 2:2, 2:1 or 1st class mark, e.g. "A 1st class mark should show evidence of insight, critical analysis and/or wider reading." Students were told at the start of the module that they were unlikely to get a first class mark if they did not read beyond just their chosen book.

\subsection{Evaluating the Book Module}

In order to evaluate the success of the Book Module, in terms of the students' experience and perceptions of it, and to gain feedback, an anonymous questionnaire was devised and distributed to the students following the examination. Appendix A reproduces the questionnaire, which made a series of statements, against which students responded on a Likert-type scale from 1 to 5 , where 1 indicates strong disagreement with the statement, and 5 indicates strong agreement. Prompts were also given to elicit further written responses in the spaces provided. A similar, shorter questionnaire was designed for academic staff feedback (Appendix B). The module was also evaluated using the university's standard quantitative questionnaire.

\section{Results and discussion}

This section presents the books selected by the students, comments on the level of achievement as indicated by the examination, and presents the results of the student and staff evaluation questionnaires. It then draws together conclusions about the merits and success of the Book Module and identifies opportunities for enhancement.

\subsection{The books}

Table 1 lists the 19 books chosen by the students in 2008-2009, and the 24 books chosen in 2009-2010. Clearly, a very broad and eclectic range of books were read. It can be concluded that if these subjects were all mastered to some extent by the staff and students of the School of Chemical Engineering and Analytical Science, then the School is considerably educated across a vast field! As noted above, a dominant emphasis in 2008-2009 was on Energy, with books on Sustainable Energy, Tomorrow's Energy and Future Energy, as well as Biofuels, Fuel Cells and Natural Gas. Sustainability was another key theme, with Sustainable Development for Engineers and Capitalism as if the World Matters in addition to Sustainable Energy. Several of the books were straightforward traditional chemical engineering (Dispelling Chemical Engineering Myths, Fundamentals of Industrial Catalytic Processes, Optimization of Chemical Processes) while others reflected the more novel areas that chemical engineers now engage with, such as Bionanotechnology, Chemical Formulations, Optoelectronics and the enzyme system Cytochrome P450 (this being a vast book on a complex subject, and one that the student regretted choosing, despite its relevance for his Research Project). The remaining books included more general interest choices such as Who Wants to be a Scientist? (which apparently had the effect of deterring the student from a scientific career) and the already mentioned The Day the World Took Off: The Origins of the Industrial Revolution. Around two-thirds of the books were selected as being directly or broadly relevant to the student's Research Project, the others being selected for broader interest rather than specific relevance. 2009-2010 saw some (six) of the same books chosen again (usually by supervisors capitalising on their investment the previous year and/or supervising similar research projects for which the same book was appropriate), with new entries reflecting the research activities within CEAS; themes included biological systems and bioprocessing (Bioseparations Engineering, Cancer - The Evolutionary Legacy, Intermolecular and Surface Forces: With Applications to Colloidal and Biological Systems, Metabolic Engineering, Microbial Fuel Cells), sensors (Microsystem Technology in Chemistry and Life Sciences, ToF-SIMS: Surface Analysis by Mass Spectrometry), mathematical modelling (Cavitation and Bubble Dynamics, Introduction to Percolation Theory, Model Building in Mathematical Programming) and chemistry (Introduction to Zeolite Molecular Sieves, Polymorphism in Molecular Crystals), as well as Smith's Chemical Process Design and Integration.

\subsection{The examination performance}

The average mark for the module was $61.4 \%$ in $2008-2009$, and $62.1 \%$ in $2009-2010$, very much in line with the performance of these cohorts of students across all their final year courses. Marks in 2008-2009 ranged from 85\% (a high first class mark) down to $43 \%$ - a bare pass, and lower than would generally be achieved by final year MEng students. This perhaps reflects the very different nature of this module relative to most chemical engineering courses, and the difficulty of some students to cope with something so atypical. In 2009-2010, the top mark was $81 \%$, with a bottom mark of $34 \%$ (a compensatable fail), again illustrating the challenge of this module for some otherwise competent students. The students scored on average very similarly for parts A and B combined, the generic questions, compared with part $\mathrm{C}$, the specific questions for each book. In general the students found the $2 \mathrm{~h}$ for the examination too short to write discursively on the general and specific questions. The fortuitous announcement of the Apple iPad on 27th January 2010, the day before the Book Module exam, allowed 
Table 1 - The books selected for reading by (a) the 2008-2009 cohort of final year MEng students; and (b) the 2009-2010 cohort.

(a) 2008-2009 cohort

"Antioxidants in Food: Practical Applications" Pokorny J, Yanishlieva N and Gordon MH (Eds.), CRC Press (2001)

"Biofuels for Transport: Global Potential and Implications for Energy and Agriculture" Worldwatch Institute, Earthscan Ltd. (2007)

"Bionanotechnology: Lessons from Nature" Goodsell DS, John Wiley and Sons Ltd. (2004)

"Capitalism as If the World Matters" Porritt J, Earthscan Ltd. (2005)

"Chemical Formulation: An Overview of Surfactant-based Preparations Used in Everyday Life" Hargreaves AE, Royal Society of Chemistry (2003)

"Cytochrome P450: Structure, Mechanism and Biochemistry" Ortiz de Montellano PR (Ed.), Springer (2005)

"Dispelling Chemical Engineering Myths" Kletz TA, CRC Press (1996)

"Elements of Physical Chemistry, 4th ed." Atkins P and de Paola J, Oxford University Press (2005)

"Fuel Cell Systems explained" Larminie JC and Dicks A, John Wiley and Sons Ltd. (2003)

"Fundamentals of Industrial Catalytic Processes" Farrauto RJ and Bartholomew CH, John Wiley and Sons Ltd. (2005)

"Fundamentals of Natural Gas Processing" Kidnay AJ and Parrish WR, CRC Press (2006)

"Future Energy: How the New Oil Industry Will Change People, Politics and Portfolios" Paul W, John Wiley and Sons Ltd. (2007)

"Optimization of Chemical Processes, 2nd Ed" Edgar TF and Himmelblau DM, McGraw-Hill Higher Education (2001)

"Optoelectronics: An Introduction" Wilson J and Hawkes J, Prentice Hall (1997)

"Sustainable Development for Engineers" Mulder K (Ed.), Greenleaf Publishing (2006)

"Sustainable Energy: Choosing Among Options" Tester JW, MIT Press (2005)

"The Day the World Took Off - the Roots of the Industrial Revolution" Dugan S and Dugan D, Channel 4 Books (2000) plus

"Chemical Engineering - the First 100 Years", Chapter 2 of "Chemical Engineering: Visions of the World" Darton RC, Wood DG and Price

RGH (Eds.), Elsevier Science (2003)

“Tomorrow's Energy: Hydrogen, Fuel Cells, and the Prospects for a Cleaner Planet" Hoffmann P, MIT Press (2002)

"Who Wants to be a scientist?: Choosing Science as a Career" Nancy Rothwell, Cambridge University Press (2002)

(b) 2009-2010 cohort

"Bioseparations Engineering: Principles, Practice and Economics" Ladisch MR, Wiley Blackwell (2001), Chapters 1-6

"Cancer - The Evolutionary Legacy" Greaves M, Oxford University Press (2000)

"Cavitation and Bubble Dynamics" Brennen CE, OUP, USA (1995)

"Chemical Formulation: An Overview of Surfactant-based Preparations Used in Everyday Life" Hargreaves AE, Royal Society of

Chemistry (2003)

"Chemical Process Design and Integration" Smith R, John Wiley and Sons (2005), selected chapters

"Flour for Man's Bread" Storck J and Teague WD, University of Minnesota Press (1952)

"Fuel Cell Systems Explained" Larminie JC and Dicks A, John Wiley and Sons Ltd. (2003), Chapters 1-7

"Fundamentals of Industrial Catalytic Processes" Farrauto RJ and Bartholomew CH, John Wiley and Sons Ltd. (2005), selected chapters

"Intermolecular and Surface Forces: With Applications to Colloidal and Biological Systems (Colloid Science)" Israelachvili JN, Academic

Press (1991), Chapters 1-12

"Introduction to Percolation Theory, 2nd revised edition" Aharony A and Stauffer D, Taylor and Francis (1994)

"Introduction to Zeolite Molecular Sieves" Dyer A, John Wiley \& Sons (1988)

plus

"Chemistry of zeolites and related porous material-synthesis and structure" Xu R, Pang W, Yu J, Huo Q and Chen J (2007), Chapter 5

"Metabolic Engineering: Principles and Methodologies", Stephanopoulos GN, Aristidou AA and Nielsen J, Academic Press (1998),

Chapters 1, 2, 3, 8

"Microbial Fuel Cells" Logan BE, John Wiley and Sons Inc. (2008)

"Microsystem Technology in Chemistry and Life Sciences" Manz A and Becker H, Springer (1997)

"Model Building in Mathematical Programming, 4th Edition" Williams HP, John Wiley and Sons (1999)

"Photocatalysis: Science and Technology (Biological and Medical Physics, Biomedical Engineering)" Kaneko M and Okura I, Springer (2002)

"Polymer Physics (Chemistry)" Rubinstein M and Colby RH, OUP Oxford, UK (2003)

"Polymorphism in Molecular Crystals" by Bernstein J, OUP (2008)

"Sustainable Development for Engineers" Mulder K (Ed.), Greenleaf Publishing (2006)

"Sustainable Energy - Without the Hot Air" MacKay DJC, UIT (2008)

"The Day the World Took Off - the Roots of the Industrial Revolution" Dugan S and Dugan D, Channel 4 Books (2000) plus

Chapter 8 of "The Ascent of Man" Bronowski J (1973)

"The Structure and Rheology of Complex Fluids" Larson RG, Oxford University Press (1999), Chapters 1-3, 9

"ToF-SIMS: Surface Analysis by Mass Spectrometry" Vickerman JC and Briggs D (Eds.), IM Publications \& Surface Spectra (2001)

plus

"Surface Analysis: The Principal Techniques" (2nd edition) Vickerman JC and Gilmore I (Eds.), Wiley (2009) Chapter 4

“Tomorrow's Energy: Hydrogen, Fuel Cells, and the Prospects for a Cleaner Planet" Hoffmann P, MIT Press (2002)

several students to draw on this in discussing the nature and future of the book.

The book reviews received an average mark of 6.8/10 over the two years, slightly higher than the examination performance. The best of the book reviews from 2008 to 2009 was sent to the Institution of Chemical Engineer's professional magazine The Chemical Engineer; this review, on Sustainable
Energy: Choosing Among Options, was published in the June 2009 issue of TCE (Matten, 2009).

\subsection{Evaluation of the Module}

A total of 15 out of the 23 students in 2008-2009 (65\%) returned their evaluation questionnaires, while the return in 2009-2010 


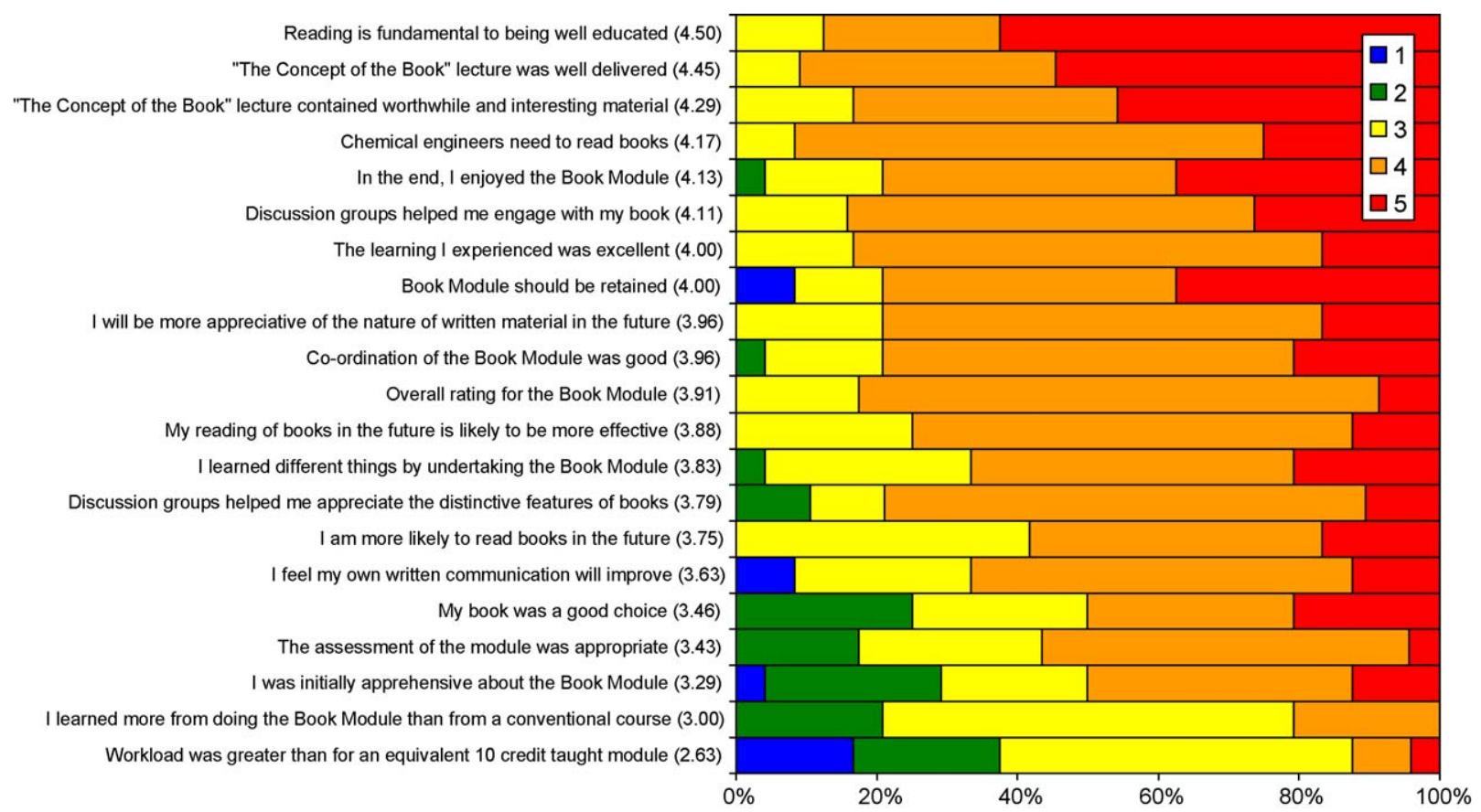

Fig. 1 - Breakdown of student responses to questionnaire statements, in which 1 corresponds to "Strongly disagree" and 5 to "Strongly agree". The number in brackets indicates the average score for each statement.

was lower (9 from 33 students, 27\%). The 2008-2009 analysis is presented in Campbell et al. (2010); the current paper presents the combined returns from the two years, giving a return rate of 24 from 56 students (43\%). Average scores were calculated against each item, and the comments compiled. A total of 229 individual comments were received over the two years, comprising a rich and eloquent resource of feedback on the module and areas for attention or improvement.

Fig. 1 presents the breakdown of scores for each item on the student questionnaire, ordered from highest to lowest average score, against an abridged version of each statement (refer to Appendix A for the full version of the statements). A general observation is that, against statements that were almost all positive in nature, fewer than $9 \%$ of the responses were $1 \mathrm{~s}$ or $2 \mathrm{~s}$ (strongly disagree or disagree), while over two-thirds (69\%) were $4 \mathrm{~s}$ or $5 \mathrm{~s}$ (agree or strongly agree), with around $23 \%$ a neutral 3. Thus it can be concluded that in general the Book Module received highly positive endorsement from the students.

(The questionnaire shown in Appendix A features 21 statements, all of which (except the first) are presented positively. The original questionnaire contained an additional statement, which was worded negatively: "Reading and being examined on a 'set text' comprising a chapter from another book, on top of the book I chose, would have been too much work and an inappropriate addition to this module." This negative wording appeared to generate some confusion in the responses (some scores did not appear to align with the corresponding comments). In 2009-2010 this statement was reworded positively, such that the results from the two years are not directly comparable for this statement. This statement has therefore been omitted from the analysis below. In both years students reported widely varying responses to this statement, with some considering it would be too much extra work or would make the module "less unique", while others considered that it would make the assessment more fair and the learning more companionable and cooperative. The wide vari- ation resulted in average scores that were close to a neutral '3'.)

Looking at the detail in Fig. 1, it can be seen that the statement "Reading is fundamental to being well educated" scored the most highly, with an average of $4.50 / 5$ over the two years of data and 15 out of 24 respondents "strongly agreeing" with the statement. The related statement "In my opinion, chemical engineers need to read books in order to undertake their professional activities effectively" also scored highly (4.17/5). It can be concluded that most of the students had indeed been persuaded of the value of reading. Thus the goal of "encouraging engineers to read" appears to have been addressed successfully.

After this, the two statements related to "The Concept of the Book" lecture scored the most highly. Comments included:

"I love history and I think the history of book is really interesting."

"Although the content of the lecture was not technically challenging it encouraged me to think about books in a different way and complemented the objectives of the module well."

"I really enjoyed this lecture, it introduced and caused me to evaluate my own learning styles, i.e. how I always print items out then highlight and take notes. Especially focusing me on how my time is most productively spent - which should help guide my studies throughout the remainder of the year."

"Makes you to realise the importance and impact of the "thing" book - that you have been taken for granted. Makes you appreciate the "book" more."

Nineteen out of the 24 respondents "agreed" (4) or "strongly agreed" (5) that in the end they enjoyed the Book Module (despite some being initially apprehensive). The related statements "The Book Module should be retained within the final year of the MEng Chemical Engineering programmes", "The learning I experienced through undertaking the Book Module was excellent", "Overall rating for the Book Module" similarly gave score profiles well above neutral, combining to give 
a positive endorsement for the Module, and with numerous supportive comments:

"It was a nice change from traditional engineering modules."

"It was nice to have a module that was such a contrast to the regular modules we do. The book module allowed me to learn about something I was particularly interested in and develop my literature critic skills."

"I really took to and engaged with the book as a concept and enjoyed the personal learning. I feel it was a good module to make the distinction between how you take responsibility for your own learning at this stage of the course."

"Great experience for me."

"It was a unique module"

"Refreshing to study in this way. Breaks up the course nicely"

"I didn't feel like I was studying for the course more like I was just acquiring knowledge for myself."

However, a comment that represents those who were more sceptical (as anticipated by Taraban, 2006), and illustrates the numerate and strategic but perhaps unimaginative character of some engineering students:

"Did not want to read a book and get examined on it during my year especially as the finally year's weighting is 6 times more than in the first year and twice as much in the second year. When considering the hard work that went in to learn the fundamentals of chemical engineering during the first 2 years, it is hard to imagine that reading a book in terms of assessment is much more important."

Fourteen of the 24 students "agreed" or "strongly agreed" that they will be "more likely to read books in the future" as a result of having undertaken the module, while the other ten were neutral on this point. However, they felt more strongly that their reading in the future will be "more effective", and even more strongly that they will be "more appreciative of the nature of written material" as a result of having undertaken the module. Comments on these aspects included:

"As my main learning source has always been books I do not think it will affect my reading however it has made me concentrate on how I use other media sources i.e. the internet and electronic books/journals."

"Having read and thought of the book outside of the pure factual content it has focused why I find some more engaging and effective."

"Certain aspects of what I researched for the book module, such as critical thinking and close reading, may well make my reading more effective in the future."

"I have always preferred reading the news compared to television - I feel that wider reading helps to put subjects into context rather than popular or politically biased opinions. I feel that this applies to learning also - through reading rather than pre-digested notes you become more aware of other issues. Create links which may be useful later, creating a more effective engineer."

Similarly, 16 of the 24 students "agreed" or "strongly agreed" that their own written communication will have improved as a result of the module, although the two responses of 1 against this statement reduced its overall average. Lufkin (1968) noted an assumption of "a direct correlation between reading habits and writing ability" - it is thus hoped that the Book Module will enhance students' writing skills, as these students acknowledged. However, a recurrent theme in the feedback was the advice that the module "could be extended into much more of a communications module with emphasis on understanding and being able to communicate effectively. Us students often comment on how people's presentation skills and ability to write English well are often the same when they start and leave university!” (sic.)

Two of the statements in the questionnaire sought to elicit perceptions regarding the amount and type of learning facilitated by the Book Module, relative to traditional chemical engineering modules, while a further statement related to the amount of work involved in this Module. The amount of work received the lowest average score and the only one lower than a neutral 3; most students found that the workload was similar to or less than a conventional 10-credit course. The average score regarding the amount of learning achieved relative to a conventional course was exactly neutral; 5 students felt they learned more, 5 felt they learned less, and 14 were neutral. However, students were much more united in agreeing that they "learned different things, things that would have been difficult to learn using the usual course structures":

"Most definitely this was the most important aspect of the book module, it allowed the development of skills that had not previously been addressed in the course."

"Different type of learning, conventional courses have more volume to remember/regurgitate whereas this was more of an experience!"

with specific skills and benefits identified as: learning how to read and analyse a book, broadening knowledge, thinking about wider issues, developing critical thinking and analysis, reading "properly", enhancing writing skills, appreciating the importance of structure and literary techniques, writing a book review, more effective use of information sources, "to appreciate reading more" and "to be patient and committed in reading a book".

The students found the discussion groups valuable, both to help them engage with their own book (average score of 4.11) and "to appreciate the distinctive and helpful features of books and of written communication" more generally (average score of 3.79). The discussion groups themselves were lively and interesting, each lasting around $2 \mathrm{~h}$.

Most students (12 of 23 - one of the 2008-2009 group did not enter a score for this statement) agreed that the assessment was appropriate, 1 strongly agreed, 6 were neutral, and 4 disagreed. With respect to assessments, students generally have an advanced sense of justice and are happy to be vocal on the subject. On this occasion, the students seemed relatively content with the assessment. The main concerns were about lack of time to answer the questions adequately, and about the relative difficulty of some of the Part $\mathrm{C}$ questions, with suggestions to weight the book review more heavily, and to add an oral examination component.

"I was pleasantly surprised by the exam questions - I liked the way you weren't expected to 'pull' it apart but more take the general themes and compare them to other sources in a more general context."

"The exam itself was enjoyable... the questions allowed the student to expand on and express their knowledge well." 


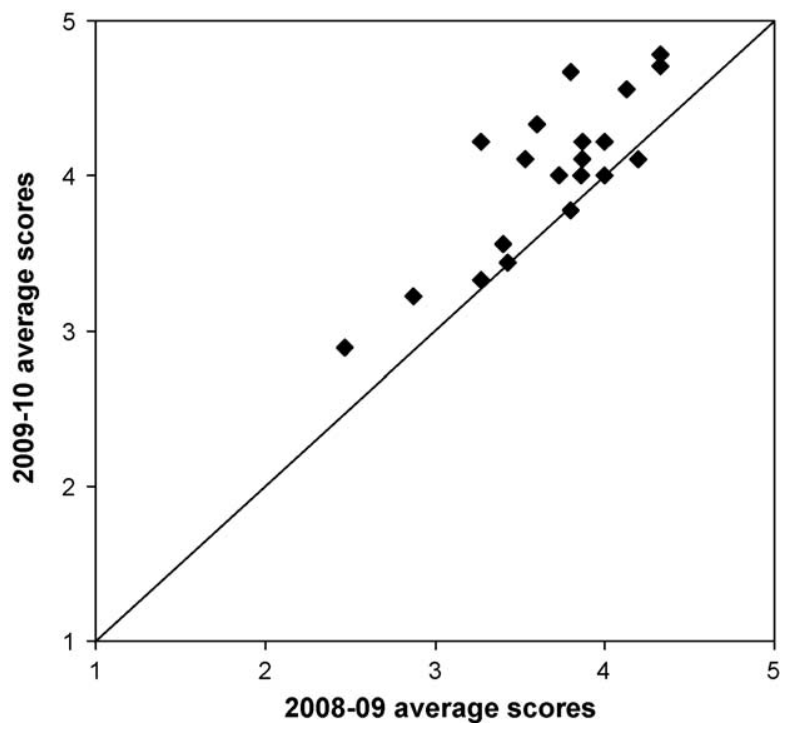

Fig. 2 - Comparison of average scores from the 2009 to 2010 cohort with the 2008 to 2009 cohort.

One-quarter of the respondents disagreed that their book was a good choice, while 7 out of the 24 agreed and 5 agreed strongly. The feedback included advice to warn future students not to choose books that are too heavily technical. The 2009-2010 cohort were happier with their choices of books (only one "disagreed"), suggesting this feedback may have benefitted them.

Finally, the majority of students agreed that the module had been well co-ordinated, with requests to obtain the books sooner in the semester to allow more time to read them, and for additional structured activities such as more lectures and discussion groups, training on essay writing, and coursework on aspects of the book/history/communication in science.

Fig. 2 compares the average scores for each statement on the student questionnaire for the two years. The figure again illustrates the overwhelmingly positive reception from the students (the data points are mostly in the top right quadrant), but also highlights the much more positive responses from the 2009 to 2010 respondents compared with the previous year. This may indicate a more positive response group rather than a more positive experience for the cohort as a whole, but it seems likely that the second year of running the module had benefitted from the experience and feedback from the first year, such that it delivered a noticeably improved learning experience. The "big wins" (large increases in average score in the second year) were for "my own written communication will improve", "in the end I enjoyed the Book Module" and "my reading is likely to be more effective". The module was run almost identically in the second year, but with an expanded "Concept of the Book" lecture and slightly more provision of supporting information, specifically the paper on document structure by Silyn-Roberts (2002), and an article by Elder (2009) on critical thinking. These papers were evidently valued at the time by students and may have contributed to the enhanced perception of the benefit of the module in these specific areas. This suggests that directed, research-based guidance about the nature of reading, critical analysis and knowledge construction could strengthen the module in relation to students' engagement with books more generally and with the specific book they choose for the module. This is explored further below.
The response to the staff questionnaire was less forthcoming, with only 11 responses over the two years (29\%). Fig. 3 shows the breakdown of the staff responses. In general, staff felt able to identify a suitable book and set an appropriate assessment for which they were confident in the mark they awarded. There appears to be a reluctant agreement that the module is worthwhile and should be retained, the reluctance arising principally from the difficulty to find time to read the book and prepare an exam question, and from a conclusion that it was "Too much effort for one student per exam paper". Anecdotal evidence supports the perception of grudging acceptance that this is a worthwhile but staff-intensive venture, very valuable for students and with tangible benefits in principle for staff, but these benefits hard to enjoy in practice. A common suggestion is to offer a small range of books, each read by a larger group of students.

Clearly the Book Module generates issues of scalability; it is difficult to run for large classes, in terms of costs and time and with respect to parity of assessment. The fact that the chemical engineering undergraduate population at Manchester is one of the largest in the country shows that this type of initiative could be implemented in most chemical engineering schools in the UK at least. However, other engineering disciplines, and indeed other science disciplines, may involve larger final year classes which would exacerbate the issues involved with transferring the approach, or the time and cost may be considered unacceptable even for smaller classes. As noted above, this could be addressed simply by offering a smaller number of books, but at the cost of the student-directed learning that was a major motivation for the module.

The issues of robustness and parity of assessment have been addressed in part above and include: the module leader taking an overview of the books with respect to length and difficulty and acting to moderate these; the module leader undertaking most of the assessment; and provision of objective descriptors of achievement to guide mark allocation for part $\mathrm{C}$, in common with general approaches for ensuring parity of assessment from different markers (as applied, for example, to assessing the components of the Research Project). The approaches taken are in line with good practice as described by, for example, Norton (2009), recognising the limitations of assessment as acknowledged by the same author and others who write about assessment. In this respect, the accuracy of assessment needs to be balanced against the importance of the individual assessment within the larger context (in this case, 10 credits out of 120 in the final year or 480 overall), and against the merits of the learning activity. It is important to acknowledge that assessment is always imperfect, particularly of higher-order learning; conversely, the more accurately a learning activity can be assessed, the less value it probably has as a learning activity. Race (1993) has put it memorably in this context: "If you can measure it, it isn't it", while others, noting the importance of reliability and validity in assessment, similarly concede "there will often be a trade-off between reliability and validity...The more reliable our estimate is of what we purport to measure, the less certain we are that we are actually measuring that aspect of attainment." (Anon, 2010). The value of the learning associated with the Book Module should not be precluded because of disproportionate concerns over absolute measures of accuracy in relation to its assessment. 


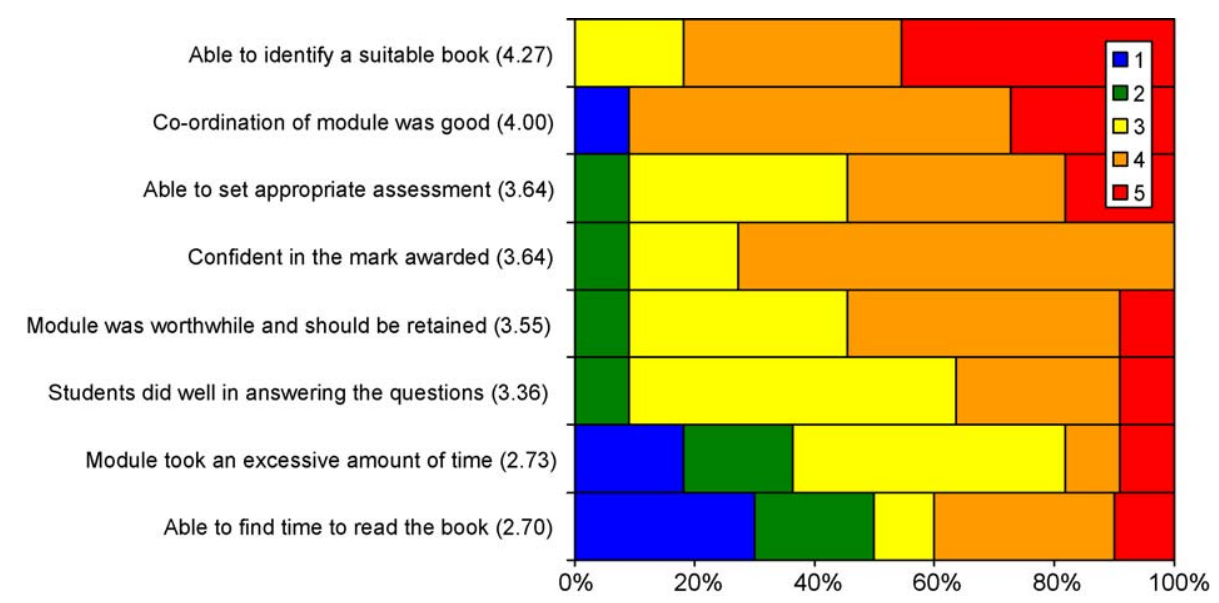

Fig. 3 - Breakdown of staff responses to questionnaire statements, in which 1 corresponds to "Strongly disagree" and 5 to "Strongly agree".

\section{Enhancing the Book Module}

The Book Module succeeded in its objectives of getting engineering students to read books independently and to respond positively to doing so; these are achievements in themselves. For some students the experience was significantly life-changing:

"Prior to beginning the book module I was reluctant to read, or as was put to us at the beginning of the book module 'retarded'... Before reading the book I wouldn't have considered the reading of a book to be an interesting experience, more of a necessity. This has constituted a major shift in my thinking... Although the book hasn't changed my 'world view'... it has changed me in a more fundamental way, giving me more of a thirst for knowledge"

Another highlighted the coherence of understanding that his book elicited and his resulting conversion to reading more technical books:

"Before doing this module I read a lot anyway so this module will not make me read more generally as I already do. However, it will make me read more technical books as I have enjoyed the module. There are many reasons why I will now read more technical books but the main one is that the book I have read for this module [Chemical Process Design and Integration] has linked together much of my previous technical knowledge into an overall coherent picture... Another reason. . . is that it was enjoyable to read a technical text without a real reason... I did not have a specific aim when reading the book and enjoyed developing my understanding of concepts and ideas. I think this will help me think creatively about engineering problems in the future and will benefit my career."

Thus the Book Module was both successful and beneficial. However, it appears there is both time and scope within the Module to enhance these benefits further. The student feedback indicated that the Module was less work than comparable 10-credit modules, and that they would appreciate additional content in the form of further reading and/or writing activities, lectures and discussion groups. The students also appeared to benefit from exposure to some formal literature on document structure and critical thinking.

As noted above, there was a recurrent suggestion from the student feedback to expand the Book Module to cover communication more generally, particularly written communication; this idea clearly has value. Tenopir and King (2005) note that "engineers and scientists spend a majority of their time communicating" (p. 5) and that "Writing is the most important skill an engineer can possess" (p. 97). Despite this, numerous commentators have lamented the poor communication skills and information literacy of engineers, particularly in relation to writing (Yackel, 1988; Tenopir and King, 2004, pp. 97ff; Keilson and Cooperstein, 2007). There is clearly a need for a communications emphasis, and particularly a writing emphasis, within the undergraduate programme. However, this needs to be sustained coherently across the three or four years of the programme, with increasingly sophisticated elements introduced in later years; a single shot would not suffice. Report writing is currently introduced within laboratory modules in the earlier years of the course. Higher level written communication is then emphasised within the Research Project that runs alongside the Book Module, with the instructional emphasis occurring in the second semester, at the time that the students are focussed on writing their dissertations and therefore receptive to the instruction. Thus the need to cultivate written communication is currently addressed elsewhere in the chemical engineering programme; the Book Module serves a distinctive, complementary purpose. That being said, following the 2008-2009 feedback, in 2009-2010 students were given the opportunity to critique their books in relation to document design and structure, based on the paper by SilynRoberts (2002). The exam paper then drew on this by asking "Evaluate how effectively your book was structured to enable retrieval and assimilation of the information. Draw on relevant research literature to support your evaluation. Give examples from your book of different levels of detail used to structure the book's information and messages, evaluating the effectiveness of each level." It was hoped that this structural analysis of the books would impact their subsequent writing in relation to the design of their dissertations.

Recognising the benefit of the Book Module in relation to communication, some students felt it would have been valuable to have located the module in an earlier year of the course. On balance, we feel that the module is best located in the final year of the MEng programmes, serving inter alia to encourage independent learning, which is one of the factors specified by the Engineering Council as distinguishing MEng-level accreditation from BEng-level (Anon., 2004). A reading-based activity in earlier years would need to address different objectives and would face practical difficulties resulting from the much larger student numbers in earlier years. Dolan and Schmidt (2006) 
describe an initiative to introduce a structured reading activity into the first year of the engineering programme at the University of Wyoming. Its location in the first year, rather than the final year as in the current work, served different objectives: to satisfy general education requirements in humanities, social sciences and the arts, to develop oral communications skills and fundamentals of information literacy, and to learn to work in team environments. In that initiative, all the students read the same book (Longitude, by Sobel (1995)), intended to provide the students with a common reading experience, but thereby contrasting with a further distinctive objective of the current work, to provide students the opportunity for self-directed (as well as independent) learning. Taraban (2006) notes the different epistemic orientations of first year students compared with senior students; the way they "value and respond to knowledge" alters with intellectual maturity ("by their senior years, students ought to recognize the relativism in knowledge, the possibility of multiple interpretations, the role of evidence, and the use of discourse in establishing consensus"). A reading activity in early years would therefore need to be directed differently to the final year initiative that is the subject of the current paper. Rather than move the Book Module as currently conceived and operated, a better option may be to introduce one or more additional, complementary reading activities in earlier years.

(Worryingly, Taraban (2006) presented evidence that engineering students' use of sophisticated reading strategies related to deep comprehension actually declined as they proceeded through the undergraduate years. He speculated that this was related to the difficult expository nature of the material engineering students typically engage with (rather than the more familiar narrative-type texts), and the focus on recall and application rather than understanding and critique. This has implications not just for the location but also for the nature of reading activities across the years of an undergraduate engineering programme. It would be worthwhile to employ formal evaluations such as those used by Taraban to measure students' use of metacognitive comprehension strategies and their beliefs about text, in order to evaluate whether the Book Module succeeded in influencing these.)

Atman and Bursic (1996) describe an experiment in which engineering students were asked to read aloud (and comment on as they read) a 13 page chapter on "The engineering approach to problem solving" prior to attempting several open-ended design problems. Those students generated more ideas and employed more sophisticated problem-solving strategies than the control group who did not read the chapter. This illustrates how reading tasks could be inserted strategically within early years of the undergraduate programme to enhance specific activities, while developing a tacit awareness of the importance of reading that would lead naturally to the Book Module in the final year.

Silyn-Roberts (2002) notes that engineering students, who naturally think in terms of design, react well to the concept of document design and hence appreciate the importance of structuring their writing. Chemical engineers are essentially process engineers, so they might also be expected to respond well to concepts of knowledge construction as a process in which reading plays a major part. As Taraban (2006) notes "Reading comprehension is an active process through which meaning is constructed." Chemical engineers who understand the process of knowledge construction through reading are likely to exhibit and develop higher levels of scientific and engineering literacy.
Taraban (2006) notes "scientific literacy in a fundamental sense encompasses all the basic abilities of skilled reading, but also includes applying higher-order skills, like distinguishing between a hypothesis and a conjecture, data and evidence, and speculations and conclusions. Scientific literacy allows the person to capture an author's intended meaning, but also to go beyond it." (Elder (2009) similarly highlights the ability to "speak in the voice of the author" as the ultimate test of critical understanding. Thus, one of the questions in the 2009-2010 exam paper asked "Why did your author(s) write their book? What were their stated purposes? What unstated purposes can you infer or suggest, based on your understanding of the author's position or agenda within the wider context?", in order to draw on this aspect of critical analysis.) Taraban (2006) then considers how engineering students develop text literacy in two specific ways: their ability to cognitively engage when processing text ("text comprehension" or growth with respect to fundamental literacy skills); and their ability to take a critical stance toward the author and material (or growth in students' orientations toward the knowledge communicated through the text). He notes that skilled readers purposefully apply multiple strategies during reading. In the context of the Book Module, it seems likely that explicitly identifying and actively cultivating higher level reading strategies, and combining this with explicit considerations of epistemology, could enhance the impact of the Book Module even further. In the context of chemical engineering, it is suggested that these students would be particularly receptive to the concept of knowledge construction as a process and of reading as an operation within that process.

\section{Reflection}

The Book Module was introduced and implemented successfully, and was very well received by students and, more grudgingly, by staff. It commendably met its stated Aims and Intended Learning Outcomes, as well as its implicit aim of encouraging engineers to read.

The initiative has been presented at several teaching and learning symposia, where it has elicited substantial interest. Principal responses have been in relation to robustness and parity of assessment, and that "You're very brave to have done this!" with respect to implementing an activity in which it was so hard to be confident of demonstrating equitable treatment of all students, and with respect to securing the contributions of so many staff.

Having implemented the module and confirmed its value over two years, the ongoing practical issues for future years revolve principally around two issues: retaining staff engagement in an activity that could be perceived increasingly as an imposition, and funding the purchase of books. The Book Module is expensive financially and in staff time. The CEEBL funding allowed the purchase of an initial resource of books that, combined with the existing and increasing library resource, could provide a sufficient pool for future students, but an important aspect of the Book Module is the opportunity to read the latest and most up-to-date books. Thus the substantial benefits of the Book Module with respect to the education of engineering graduates must be weighed against the tangible costs and demands on staff.

Finally, we return to the distinctive feature of chemical engineering as the broadest of the engineering disciplines. It follows that the distinctive obligations of chemical engineers 
include the need to cultivate breadth of perspective, and the need to engage with change on the broadest of fronts. Encouraging reading, as the basis for education at its most profound, problem solving at its most creative and lifelong learning at its most sustained, seems particularly appropriate for chemical engineers.

\section{Acknowledgements}

The authors gratefully acknowledge the funding from the University of Manchester's Centre of Excellence for Enquiry-Based Learning that allowed this project to proceed. The authors are also grateful to the staff of the School of Chemical Engineering and Analytical Science, and to the MEng classes of 2008-2009 and 2009-2010, for their participation in and feedback on this novel learning activity.

\section{Appendix A.}

Statements on student feedback questionnaire (to which students responded on a scale of $1-5$, where 1 corresponds to "Strongly disagree" and 5 to "Strongly agree"), and additional prompts.

Please write comments about any aspect of the module (even if not specifically requested) in the spaces provided or at the end

I was initially apprehensive about the Book Module.

Why or why not?

In the end, I enjoyed the Book Module.

Why or why not?

My book was a good choice.

Why or why not? (briefly)

I feel I learned more by doing the Book Module than I would have learned from a conventional 10-credit taught course $(1=$ No, I learned a lot less; $3=$ about the same; $5=$ a lot more).

Why or why not?

I feel I learned different things by undertaking the Book Module, things that would have been difficult to learn using the usual course structures.

What sort of things?

The assessment of this module was appropriate.

Please add comments on the assessment and any suggestions for improvement.

The co-ordination of the Book Module was good.

Any comments or suggestions for improvement:

The lecture on "The Concept of the Book" contained worthwhile and interesting material.

Comments:

The lecture on "The Concept of the Book" was well delivered.

Comments:

The discussion groups helped me engage with my book.

Omit this if you did not attend a discussion group. If you did attend, what, if anything, did you find helpful?
The discussion groups helped me appreciate the distinctive and helpful features of books and of written communication

I am more likely to read books in the future as the result of having undertaken this Book Module.

( 3 = not more likely but not less likely; 1 = less likely - I've been put off books!)

My reading of books in the future is likely to be more effective as a result of having undertaken this Book Module.

I will be more appreciative of the nature of written material in the future, through having undertaken this Book Module.

I feel my own written communication will improve as a result of having studied books and the nature of reading and communication through this Book Module.

If so, in what way?

Reading is fundamental to being well educated.

In my opinion, chemical engineers need to read books in order to undertake their professional activities effectively. Why or why not?

The Book Module should be retained within the final year of the MEng Chemical Engineering programmes.

Why or why not? Should it be dropped, extended, placed elsewhere, modified in some way?

The workload associated with this module was much greater than for an equivalent 10-credit taught module. $(1=$ No, it was a lot less work; $3=$ about the same; $5=a$ lot more).

The learning I experienced through undertaking the Book Module was excellent.

Overall rating for the Book Module.

Any other comments:

\section{Appendix B.}

Statements on staff feedback questionnaire (to which students responded on a scale of $1-5$, where 1 corresponds to "Strongly disagree" and 5 to "Strongly agree"), and additional prompts.

I was able to identify a suitable book to offer for the book exam - one that was of interest to me to read, and one that was suitable for students to study.

Comments:

I was able to find time to read my chosen book, and doing so was a worthwhile investment of my time.

I was able to set appropriate assessment questions based on my book.

Any difficulties in setting the assessment?

The student(s) did well in answering the questions I set.

( 1 = disappointed my expectations; 3 = met my

expectations; 5 = exceeded my expectations). 
I am confident that the mark awarded was appropriate.

The co-ordination of the Book Module was good.

Any suggestions for improvement:

The Book Module took up an excessive amount of my time, relative to the teaching and learning achieved.

The Book Module was worthwhile and should be retained as part of the MEng final year programme.

Any further comments or suggestions:

\section{References}

Abdul Karim, N.S., Hasan, A., 2007. Reading habits and attitude in the digital age: Analysis of gender and academic program differences in Malaysia. The Electronic Library 25 (3), 285-298.

Anonymous, 2004. The Accreditation of Higher Education Programmes, The Engineering Council, London, UK.

Anonymous, 2009. http://en.wikipedia.org/wiki/DIKW, accessed 28th July 2009.

Anonymous, 2010. http://en.wikipedia.org/wiki/Assessment, accessed 7th July 2010.

Atman, C.J., Bursic, K.M., 1996. Teaching engineering design: can reading a textbook make a difference? Research in Engineering Design 8, 240-250.

Campbell, G.M., Blunden-Ellis J., Manista F., 2010. Encouraging Engineers to Read: A Book-Based Final Year Assessment. In: Aubrey, A., Chilton, T., Comer, K., Manista, F., Powell, N.J. (Eds.), Case Studies: CEEBL-Supported Projects 2008-10. Centre for Excellence in Enquiry-Based Learning, University of Manchester, pp. 30-50.

Covey, S.R., 1989. The Seven Habits of Highly Effective People. Simon and Schuster, New York, USA.

Dolan, C., Schmidt, L., 2006. Integration of Freshman Engineering Program into the All University Freshman Reading Initiative. American Society for Engineering Education, Chicago, IL, United States.

Elder, L., 2009. I think critically, therefore I am. Times Higher Education, 6th August 2009, 36-39.
Hutchins, R.M., 1952. The Great Conversation: The Substance of a Liberal Education. Encyclopaedia Britannica Inc, Chicago, USA.

Keilson, S., Cooperstein, S., 2007. Work in progress - Information literacy, plagiarism and engineering education. In: Proceedings of 37th ASEE/IEEE Frontiers in Education Conference, Institute of Electrical and Electronics Engineers Inc., Milwaukee, USA.

Lufkin, J.M., 1968. On reading habits of engineer-authors. IEEE Transactions on Engineering Writing and Speech EWS-11, 17.

Lufkin, J.M., Miller, E.H., 1966. The reading habits of engineers: a preliminary survey. IEEE Transactions on Education E-9 (4), 179-182.

Matten, A.F., 2009 June. Book review "sustainable energy: choosing among options". The Chemical Engineer, 51.

Norton, L., 2009. Assessing student learning. In: Fry, H., Ketteridge, S., Marshall, S. (Eds.), A Handbook for Teaching and Learning in Higher Education: Enhancing Academic Practice, 3rd Edition. Routledge, Abingdon, UK, pp. 132-149, Chapter 10.

Perkins, J.D., 2003. Chemical engineering - the first 100 years. In: Darton, R.C., Prince, R.G.H., Wood, D.G. (Eds.), Chemical Engineering: Visions of the World. Elsevier Science, pp. 11-40.

Race, P., 1993. Never Mind the Teaching - Feel the Learning, SEDA Paper 80, Chapter 1, SEDA Publications, Birmingham.

Salwak, D., 2008. Teaching Life: Letters from a Life in Literature. University of Iowa Press, USA.

Silyn-Roberts, H., 2002. Document structure and its effect on engineers' reading strategies. Journal of Professional Issues in Engineering Education and Practice 128, 115-119.

Sobel, D, 1995. Longitude, the True Story of a Lone Genius who Solved the Greatest Scientific Problem of His Time. Penguin Books, NY, USA.

Spurlin, J.E., Rajala, S.A., Lavelle, J.P. (Eds.), 2008. Designing Better Engineering Education through Assessment. Stylus Publishing, Virginia, USA.

Taraban, R., 2006. The growth of text literacy in engineering undergraduates. In: Proceedings of the 2006 American Society for Engineering Education Annual Conference, Chicago, IL, United States.

Tenopir, C., King, D.W., 2004. Communication Patterns of Engineers. John Wiley \& Sons, Hoboken, New Jersey, USA.

Yackel, D.C., 1988. Engineers and Literacy. Chemical Engineering $95,7$. 